Irq J Pharm

Vol. $\vee \& \wedge$, No. ', , r..

\title{
The effect of rofecoxib and diclofenac on blood picture in male patients
}

\author{
Mohammed Z.K. Al-Hayali*, Faris A. Ahmed. ** \\ *Directorate of Health, Mosul. **Department of physiology, Ninevah college of Medicine University of Mosul.
}

\begin{tabular}{|c|c|}
\hline Received: & Accepted \\
\hline $1 \cdot .1 \cdot r \ldots v$ & $\vee .1 . r \ldots \wedge$ \\
\hline
\end{tabular}

\section{ABSTRAT}

Objectives: To assess the effect of roficoxib and also the effect of diclofenac as a standard nonsteroidal anti-inflammatory drug (NSAD) on complete blood picture.

Methods: Complete blood picture was taken for $r q$ male patients on roficoxib therapy at $r_{0} \mathrm{mg} / \mathrm{day}$ for $\mid\{-Y \mid$ consecutive days. Complete blood picture was also taken for 10 male patients on roficoxib thearapy at $1 \cdots \mathrm{mg} /$ day for $\left|\varepsilon_{-} r\right|$ consecutive days. Comparison was made between measurements of blood picture before and at the end of treatment by using Students paired t-test.

Results: Roficoxib or diclofenac showed no significant changes in complete blood picture in the male patients in comparison with the measurements before treatment.

Conclusion: Roficoxib or diclofenac has no significant effect on blood picture in patients when used for short term with moderate doses.

Keywords: roficoxib, diclofenc, complete blood picture.

الخلاصة

مقدمة: لدر اسة تاثثير عقار روفيكوكسب على فحوصات الدم الكاملة كذلك لدر اسة ناثير عقاردايكلوفيناك كعقار قياسي غير

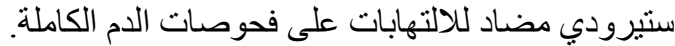

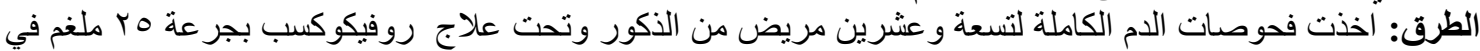

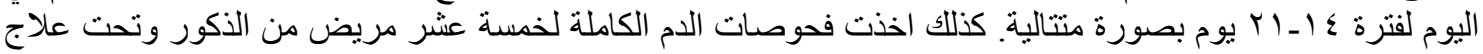

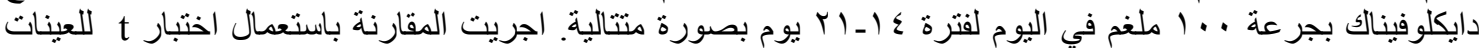

المتر ابطة.

النتائج: لم يظهر عقار روفيكوكسب او عقار دايكلوفيناك أي تغيير معنوي في فحوصات الدم الكاملة في المرضى الذكور

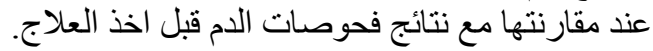

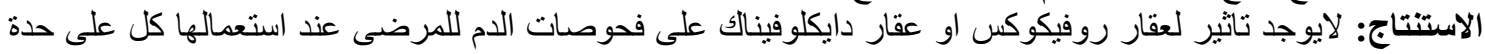
ولفترة قصبيرة وبجر عة متوسطة.

$\mathbf{R}$ ofecoxib is a specific cyclooxygenase- $r$ $(\mathrm{COX}-r)$ inhibitor and its benifical action is similar to the traditional nonsteroidal antiinflammatory drugs (NSAIDs) indicating similar analgesic and anti-inflammatory effects.' Clinical studies of rofecoxib have demonstrated efficacy equivalent to COX nonselective NSAIDs with lower rates of gastrointestinal tract side effects like endoscopic ulcers.' Clearly,
COX-r selective inhibitors offered logical choices to alliterate pain and inflammation with fewer side effects.

Diclofenac shows a high degree of antiinflammatory, analgesic and antipyretic activity. .

In comparison with refecoxib, diclofenac is a potent relatively nonselective COX inhibitor in 
addition diclofenac can reduce arachidonic acid bioavailability.

The haematological effects of traditional NSAIDs induced two opposing actions, in one hand, NSAIDs inhibited prostaglandins (PGS) mediated inhibition of cytokines there by increasing stem cells and colony forming unit (CFU) proliferation and differentiation, on the other hand, NSAIDs inhibited PGS mediated stimulation of erythropoietin release and consequently inhibiting the maturation of erythrocyte line.'

COX- $r$ derived PGS play the potential role in the control of cytokines production and consequent haematopoiesi. ${ }^{\vee}$ However, both COX-1 and COX-r derived PGE may play a role in the control of erythrocyte maturation. ${ }^{\wedge}$ COX-r deficiency appears to inhibit the onset or the rate of haematopoiesis under tension conditions, but unlikely compromising eventually full haematological recovery.

This study has been done to investigate the effect of rofecoxib and diclofenac on complete blood picture in male patients.

\section{Patients and methods}

This study was carried out in the department of Rheumatology and in the Haematology laboratory at Al-Salam Hospital in Mosul city, from January to July $r \ldots \varepsilon$, under the supervision of haematologists in the hospital.

Patients with rheumatological diseases or post-operative pain were excluded from the study. In addition, erythrocyte sedimentation rate (ESR) test was made to exclude the presence of other concurrent diseases. Complete blood picture was made at about 1. . a.m. to avoid diurnal variation.' Blood samples were taken from patients while they were sitting, since Penev and Kereshka " found that position of patients affects complete blood picture.
Male patients were included, who complained from simple pain like backache or joint pain. The duration of treatment was between $\mid \varepsilon_{-} r$, days. The studied groups were divided into two groups. The first group included $r q$ patients given rofecoxib (Inflaix, Ajanta Pharma Limited, India), ( $r \circ \mathrm{mg} /$ day), their ages ranged between $r q-\leqslant q$ years (mean $\pm S D$ : $r \uparrow . \wedge \pm \wedge . q$ years). The second group included 10 patients given diclofenac sodium (voldic S.R., pharma. International co, Amman, Jordan), ( $\cdots \mathrm{mg} / \mathrm{day}$ sustained release), with age range between $r$ r « (mean $\pm S D:$ r $0.0 \pm \tau . r$ years).

Venous blood sample $(r . \circ \mathrm{ml})$ was taken from the participants by venipuncture. The blood was placed in r.o ml EDTA (ethylene diamine tetraacetic acid) tubes. The samples were mixed well and placed on a mechanical shaker. The tests were done within the first hour after sample collection. Total white blood cell (WBC), platelets, differential WBC and reticulocyte counts were performed by using a manual microscopic method. ${ }^{r, i r}$ Packed cell volume (PCV) and haemoglobin $(\mathrm{Hb})$ were measured by microhaematocrit and Drabkin's solution methods, respectively ${ }^{r},{ }^{r}$. Westergren method was used for measurement of $\mathrm{ESR}^{(1 \xi)}$.

\section{Results}

No significant changes were found in $\mathrm{Hb}$ (haemoglobin), PCV (packed cell volume), reticulocyte, total and differential WBC, and platelet count in patient treated with rofecoxib for $\mid\{-r \mid$ days $(n-r q)$ in comparison with those measurements before treatment ( Table ').

No significant changes were found in $\mathrm{Hb}$, PCV, reticulocytes, total and differenetial WBC, and platelet counts in patients treated with diclofenac for $\left|\varepsilon_{-} r\right|$ days in comparison with these measurements before treatment (Table $r$ ).

Table '. Blood picture of rofecoxib in patients before and after treatment. 
Irq J Pharm

Vol. $\vee \& \wedge$, No. $), ~ r \ldots \wedge$

\begin{tabular}{|c|c|c|c|}
\hline \multirow{2}{*}{ Parameters } & \multicolumn{2}{|c|}{ Means \pm SD $(n=r q)$} & \multirow{2}{*}{ Significance } \\
\hline & Before treatment & After treatment & \\
\hline $\mathrm{Hb}(\mathrm{g} / \mathrm{L})$ & $1 \pi 4 . \wedge 7 \pm 11 . Y \varepsilon$ & $1 \leqslant \cdot .1 \leqslant \pm 1 Y .70$ & NS \\
\hline PCV (\%) & $\cdot \varepsilon r_{ \pm} \cdot . \cdot 0$ & $\cdot . \varepsilon \pm \cdot . \cdot \varepsilon$ & NS \\
\hline Total WBC cont $\times 1 \cdot{ }^{7} / \mathrm{L}$ & $\frac{1.1 \cdot \pm 1.91}{1}$ & $V_{.} \cdot r \pm r . \cdot 1$ & NS \\
\hline \multicolumn{4}{|c|}{ Differential WBC count $(\%)$} \\
\hline Neutrophils & $4 . .7 \pm \pm 1 \cdot . \cdot 4$ & $74.1 \cdot \pm \wedge .00$ & NS \\
\hline Lymphocytes & $r r . \leqslant 0 \pm 9 . Y \leqslant$ & $r \cdot r ! \pm V . \wedge 0$ & NS \\
\hline Monocytes & $\cdot .79 \pm 1 . \varepsilon V$ & $\cdot . \Upsilon \wedge \pm \cdot . \wedge \varepsilon$ & NS \\
\hline Eosinophils & $r \cdot Y \pm r . A r$ & $r . r \pm \Psi . \wedge \Lambda$ & NS \\
\hline \multicolumn{4}{|c|}{ Differential WBC absolute count $x 1 \cdot{ }^{4} / L$} \\
\hline Neutrophils & $\varepsilon .00 \pm 1.00$ & $\varepsilon .7 \wedge \pm 1.70$ & NS \\
\hline Lymphocytes & $r . r O \pm \cdot . \wedge V$ & $r . \wedge \pm \cdot . \vee \varepsilon$ & NS \\
\hline Monocytes & $\because .0 \pm \cdot .11$ & $\because \cdot r \pm \cdot \cdot \cdot 0$ & NS \\
\hline Eosinophils & $.10 \pm \cdot .10$ & $\cdot r \leqslant \pm \cdot . r$ & NS \\
\hline Platelet count $x 1 \cdot 1 / \mathrm{L}$ & $r \varepsilon \cdot . \mid V \pm \sum r ! . \wedge$ & $r \leqslant \wedge . Y \wedge \pm \leqslant \wedge . \leqslant 1$ & NS \\
\hline
\end{tabular}

NS, insignificant, $\mathrm{P}<\cdot . \bullet$

Table r. Blood picture of diclofenac patients before and after treatment.

\begin{tabular}{|c|c|c|c|}
\hline \multirow[t]{2}{*}{ Parameters } & \multicolumn{2}{|c|}{ Means $\pm S D(n=r q)$} & \multirow[t]{2}{*}{ Significance } \\
\hline & Before treatment & After treatment & \\
\hline $\mathrm{Hb}(\mathrm{g} / \mathrm{L})$ & $1 \leq \cdot . r \pm \pm 11 . Y \Lambda$ & $1 \% \wedge . \vee \varepsilon \pm 1 \cdot . V \cdot$ & NS \\
\hline PCV (\%) & $\cdot . \varepsilon \pm \cdot . \cdot r$ & $\cdot . \varepsilon \pm \cdot . r$ & NS \\
\hline Reticulocytes (\%) & $\cdot \wedge \leqslant \pm \cdot \vee \vee q$ & $\cdot \vee \wedge \pm \cdot . \vee \nearrow$ & NS \\
\hline \multicolumn{4}{|c|}{ Differential WBC count (\%) } \\
\hline Neutrophils & 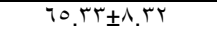 & $T r . \Sigma V \pm T . \wedge \varepsilon$ & NS \\
\hline Lymphocytes & 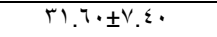 & $r \leqslant . T V \pm V . \wedge r$ & NS \\
\hline Neutrophils & $\varepsilon .1 \wedge \pm 1 . Y V$ & $\varepsilon . \wedge \pm 1.1 \vee$ & NS \\
\hline Lymphocytes & $1.97 \pm \cdot .7$ & $r . r q \pm \cdot . v 1$ & NS \\
\hline Monocytes & $\because \cdot r \pm \cdot .0$ & $\because \cdot Y \pm \cdot \cdot r$ & NS \\
\hline Eosinophils & $\cdot .1 Y \pm \cdot . I V$ & $.19 \pm \cdot . Y_{0}$ & NS \\
\hline $\begin{array}{l}\text { Platelet count } \\
\text { x } 1 \cdot 9 / \mathrm{L}\end{array}$ & $r V 7 . T V \pm V 0.11$ & $r \| . r r \pm 7 \lambda .1 r$ & NS \\
\hline
\end{tabular}

NS, insignificant, $P<\cdot . \bullet$

\section{Discussion}


In the rofecoxib treated patients, complete blood picture was not significantly different from pretreatment values. These results are in agreement with other studies. ${ }^{10,1 /}$ These authors did not find any significant effect of short-term use of rofecoxib on complete blood picture. However, COX- $r$ inhibition in vitro and in vivo was associated with increased WBC count in the peripheral blood including granulocyte, monocytes and lymphocytes. Accordingly, the short duration and moderate dose might not be enough to significantly affect the blood picture.

In this study, complete blood picture was not significantly different in diclofenac treated patients in comparison with the pretreatment values. These results were in agreement with other studies.' ${ }^{\prime \prime, ' \wedge}$ Emery et al. ${ }^{\prime v}$ found that the haematological effect of diclofenac required long term use. Moreover, Hofer et al. ${ }^{19}$ found that the effect of diclofenac on blood required the use of toxic doses. Thus, the short term duration and the moderate dose of diclofenac, in this study, might be contributing factors for the lack of significant effects on the blood picture.

Non-steroidal antiinflammatery drugs and COX-r selective inhibitors affect the function rather than proliferation of platelets where they can change the haemostasis by tipping the balance that is naturally occurring between the prothrombic thromboxine $A_{r}\left(T X A_{r}\right)$ and anthithrombic prostacycline $\left(\mathrm{PGI}_{\mathrm{r}}\right){ }^{r}{ }^{r}$ In addition, roficoxib diminished platelet aggregation and inhibited-mediated thrombosis in vitro model of thrombosis."

In conclusion, short term use of moderate dose of diclofenac or rofecoxib has no effect on blood picture in patients suffering from miner pain.

\section{References}

1- Evert's B, Wahrborg P, Hedner T. COX-r specific inhibitors- the emergence of a new class of analgesic and anti-inflammatory drug. Clinc Rheumatol $r \cdots, 19: r r 1-r \leqslant r$.

r- Brooks P, Emery P, Evans JF, Fenner $\mathrm{H}$ et al. Interpreting the clinical significance of the differential inhibition of cyclooxygenase- 1 and cyclooxygenase-r. Rheumatology

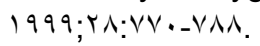

r..A Mosul College of Pharmacy r- Raskin JB. Gastrointestinal effects of non steroidal anti-inflammatory therapy. Am J Med 1999; 1. 7 : rs-1rs.

\&- Menasse R, Hedwall PR, Kraetz $J$ et al. pharmacological properties of diclofenac sodium and its metabolites. Scand $J$ Rheumatol supp 19vA;rr:0-17.

o- Furst, munster T. Nonsteroidal antiinflammatory drugs, disease- modifying antirheumatic drugs, nonopioid analgesics and drug used in gout. In katzung BG eds. Basic and clinical pharmacology. New York: Lang Medical booked McGraw-Hill Y.. I: T. Y T.V.

7- Kozubik A, Pospisil M, Viklicka S et al. Effect of indomethacin on the proliferative and differentiation activity in the haemopoietic system of lethally irradiated mice after syngeneic bone marrow transplantation.

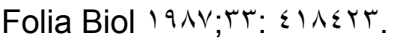

V- Hartel C, Puttkamer JV, Gallner F et al. Dose-dependent Immunomodulatory effects of acetylsalicylic acid and indomethacin in human whole blood potential role of cyclooxygenase- $r$ inhibition. Scand J Immun $r \cdot . \leqslant ; r \cdot: \leqslant 1 r-\varepsilon r \cdot$

A- Rocca B, Secchierob P, Ranellettic et al. Modalation of the expression and activity of cyclooxygenase in normal and accelerated erythropiesis. Exp Haematol $r \cdot . \varepsilon ; r^{\prime}(1 \cdot)$ : 9r $\leqslant-9 T \leqslant$.

१- Lorenz M, Slaughter HS, Westott DM et al. Cyclooxygenase-r is essential for normal recovery from o-fluorouracil induced myelotoxicity in mice. Exp Haematol 1999; $r V: 1 \leq 9 \leq-10 . r$.

1.- Statland BE, Winkel P, Harris SC et al. Evaluation of biologic sources of variation of leukocyte counts another hematologic quantities using very precise automated

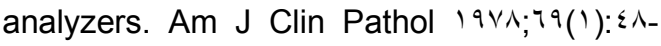
0 .

1)- Penev M, Kereshka P. Effect of body position on laboratory hematological indices. Vutr Boles 1999; rv(₹): T9-Vr.

1Y- Haen PJ. Principles of Hemalology. WCB,

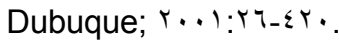

1\%- Bain BJ, Bates I. Basic haematological techniques. In Lewis SM, Bain BJ, Bates I eds. Dacie and Lewis Practical 
Irq J Pharm Vol. $\vee \& \wedge$, No. ',,$\ldots \wedge$

Haematology, $9^{\text {th }}$ ed, London: Churchill Livingstone $r \ldots$. $;$, 9 -r. .

I $\leq$ - Lewis SM. Miscellaneous tests. In Lewis SM, Bain BJ, Bates I eds. London: Churchill Livingstone r... 1; orv_or^.

10. Morrison BW, Fricke J, Brown J et al. The optimal analgesic dose of rofecoxib. J Am Dent Assoc r...; ; r I: $1 \vee r q-1 \vee r v$.

1 工. Merk and Co. Vioxx prescribing information r...r.

IV- Emery $\mathrm{P}$, Zeidler $\mathrm{H}$, Kvien et al. celecoxib versus diclofenac in long term management of rheumatoid arthritis: randomized double blind comparison. Lancet $1999 ; r_{0} \leqslant: Y 1 \cdot r_{-}$ rill.
1 ^- Silverstein FE, Faich G, Goldstein JL et al. Gastrointestinal anti-inflammatory drug for osteoarthritis and rheumatoid arthritis. JAMA $r \ldots, r \wedge \varepsilon: 1 r \leqslant v_{-} 1 r_{00}$.

19- Hofer M, Pospisil M, Pipalova I et al. modulation haemopoietic radiation response of mice by diclofenac in fractionated treatment. Physiol Res 1997; so(r): rIT-rr.

r.- Mukherjec D, Nissen SE, Topol EJ et al. COX-r inhibitors and cardiovascular risk, we defend our data and suggest caution. Clev Clinic J Med r... ; r^(1'): 9 тr-9 ז .

r) - Hemandez MR, Tonda R, Pino M et al. Evaluation of roficoxib on platelet function in an in vitro model of thrombosis with circulating human blood. Eu J Clin Invest r... $\leqslant ; r \varepsilon(\varepsilon): r q \vee-r \cdot r$. 